\title{
Habitat Preference of Rats at Bawakaraeng Mountain, South Sulawesi, Indonesia
}

\author{
Ahmad Hasyim \\ Faculty of Mathematics and Science \\ STKIP Pembangunan Indonesia \\ Makassar, South Sulawesi, Indonesia
}

\author{
Andi Bida Purnamasari \\ Faculty of Engineering \\ STKIP Pembangunan Indonesia \\ Makassar, South Sulawesi, Indonesia \\ bidapurnamasari@gmail.com
}

\author{
Muh. Rizaldi Trias Jaya Putra \\ Faculty of Language \\ STKIP Pembangunan Indonesia \\ Makassar, South Sulawesi, Indonesia
}

\begin{abstract}
The study was conducted at Bawakaraeng mount in four height level that is at an altitude of $1300,1700,1900$, and 2200 meters above sea level. Sampling was done three times repetitions at each height level as well as the use of 200 mouse trap consists of a live trap and dead trap. Rats were caught later identified and numbered as initial data. A total of 227 individuals (4 genera; 10 species) that is Rattus hoffmani, Rattus dammermani, Rattus exulans, Bunomys andrewsi, Bunomys chrysocomus, Bunomys heinrichi, Taeromys celebensis, Taeromys hamatus, Paruromys dominator, and Paruromys sp. Habitat Preference analyzed based on Euclidean dissimilarity index, the analysis result of the dendrogram of each type and altitude levels of rats habitat type was indicated that the habitat preference at the site of primary forest $(2200 \mathrm{~m}$ asl) and degradation forest $(1500 \mathrm{~m}$ asl $)$ is more dominant than the other habitats.
\end{abstract}

Keywords: rat; Bawakaraeng Mount; habitat preference; Euclidean dissimilarity index

\section{INTRODUCTION}

Indonesia is one of the mega biodiversity country, which has about 701 species of mammals [1]. Rats are one type of small mammals; rats are rodents known as pests of crops and spreader zoonotic diseases. Rats occupy various types of habitats, including forests, gardens, fields, human settlements, urban and rural [2]. Rats formed an important component of the ecosystem, which plays a major role in the food chain. Until now the Rat in the Order Rodentia and Muridae family consists of five subfamily known, one subfamily is Murinae composed of 129 genera and 584 species [3].

Distribution and diversity of the rats are influenced by environmental factors such as the density of vegetation, climate, altitude, habitat, food sources, disease, predation and habitat exploitation by humans [4], [5]. Before the study was conducted, several species of rat consists of 47 species of rodent are scattered throughout the region of Sulawesi, and has a highest endemic [1], [6]. Sulawesi is one of the islands located in the State of Indonesia and also one of the areas that have high species diversity [7]. Although the publication on the type of rats that comes from Sulawesi has been done, little is known about the habitat preference about the height level [1], [8].

\section{RESEARCH METHODS}

This research was conducted for three months from September to November 2013. A total of four altitude levels, 1300 to 2200 meters above sea level (m asl). Five height level is divided into $1300-1499 \mathrm{~m}$ asl, $1500-1699 \mathrm{~m}$ asl, 1700-1899 $\mathrm{m}$ asl, 1900-2099 $\mathrm{m}$ asl and $2200 \mathrm{~m}$ asl. Catching rats performed by using two types of traps that as many as 100 dead traps and as many as 100 live traps. The entire trap then gave desiccated feed coconut as an attraction. Traps placed randomly with time estimates of different heights in each level. Rats were caught and then do the marking by mentioning the number of specimens that will provide information about the name of the location, date, month, year, gender, age, and height of the level, further samples of rats preserved in $10 \%$ formalin for identification.

Specimens rats found described and counted the number of individuals $(\mathrm{N})$ and Number of species (S). Selection of rat habitat will be calculated based on altitude levels to use Euclidean dissimilarity index in the form of clusters using Paleontological Statistics for Windows program (Colwell 2013).

\section{RESULTS AND DISCUSSION}

A total of 227 rats were caught individuals (4 genera; 10 species) is found in various altitude levels ranging from 1300 to $2200 \mathrm{~m}$ above sea level. The types are: Rattus hoffmani, Rattusdommermani, Rattus exulans, Bunomys andrewsi, Bunomys chrysocomus, Bunomys heinrichi, Taeromys celebensis, Taeromys hamatus, Paruromys dominator, and Paruromys sp. 
TABLE I. THE NUMBER OF SPECIES AND INDIVIDUALS OF RATS IN EACH HEIGHT LEVELS

\begin{tabular}{|c|c|c|c|c|c|}
\hline \multirow{2}{*}{ Species } & \multicolumn{5}{|c|}{ Height levels } \\
\hline & $\begin{array}{l}1300 \\
\text { masl }\end{array}$ & $\begin{array}{l}1500 \\
\text { masl }\end{array}$ & $\begin{array}{l}1700 \\
\text { masl }\end{array}$ & $\begin{array}{l}1900 \\
\text { masl }\end{array}$ & $\begin{array}{l}2200 \\
\text { masl }\end{array}$ \\
\hline $\begin{array}{l}\text { Rattus } \\
\text { hoffmani }\end{array}$ & .0031 & .0100 & .0038 & .0183 & .0130 \\
\hline $\begin{array}{l}\text { Rattus } \\
\text { dommermani }\end{array}$ & .0072 & .0031 & .0000 & .0017 & .0040 \\
\hline $\begin{array}{l}\text { Rattus } \\
\text { exulans }\end{array}$ & .0133 & .0277 & .0200 & .0067 & .0030 \\
\hline $\begin{array}{l}\text { Bunomys } \\
\text { andrewsi }\end{array}$ & .0003 & .0031 & .0000 & .0033 & .0020 \\
\hline $\begin{array}{l}\text { Bunomys } \\
\text { chrysocomus }\end{array}$ & .0000 & .0008 & .0038 & .0033 & .0040 \\
\hline $\begin{array}{l}\text { Bunomys } \\
\text { heinrichi }\end{array}$ & .0000 & .0023 & .0000 & .0033 & .0020 \\
\hline $\begin{array}{l}\text { Taeromys } \\
\text { celebensis }\end{array}$ & .0000 & .0023 & .0000 & .0000 & .0010 \\
\hline $\begin{array}{l}\text { Taeromys } \\
\text { hamatus }\end{array}$ & .0000 & .0015 & .0000 & .0000 & .0000 \\
\hline $\begin{array}{l}\text { Paruromys } \\
\text { dominator }\end{array}$ & .0000 & .0000 & .0000 & .0000 & .0010 \\
\hline Paruromys $s p$ & .0000 & .0000 & .0000 & .0000 & .0010 \\
\hline
\end{tabular}

Rat species are grouped into the inequality index Euclidian distance (EDD) (shown in Figure 1), the ten species are grouped into four main groups. This group consists of species associated with several types of habitat that the species found at an altitude of $1300-2200 \mathrm{~m}$ above sea level.

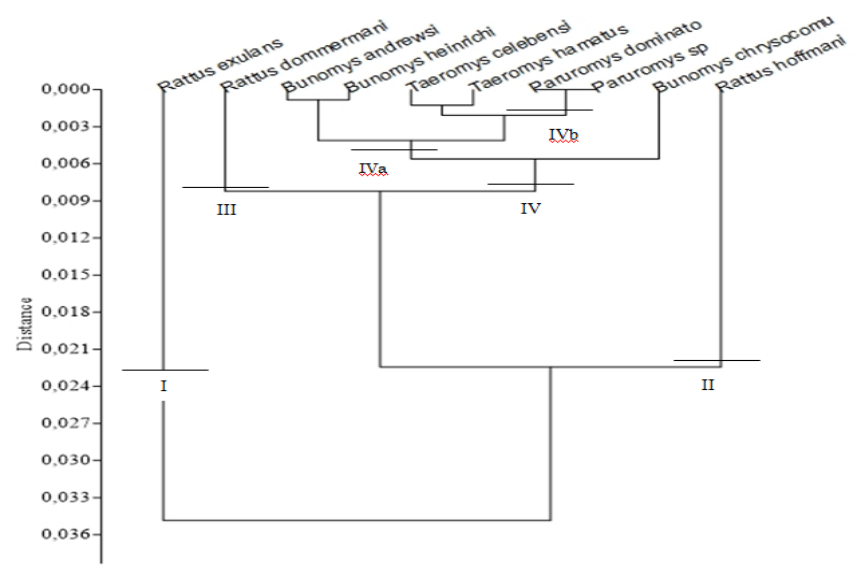

Fig. 1. Dendrogram inequality strains of rat at each height level based on Euclidian index

Group I consists of R.exulans, found in the plantation habitat $(1300 \mathrm{~m}$ asl), degraded forests $(1500 \mathrm{~m}$ above sea level), pine forests (1700 m asl), secondary forest (1900 m asl) and primary forest $(2200 \mathrm{~m}$ asl $)$. Some individuals mostly found in the area of degraded forest plantations. The fewest number of individuals found in forest habitats are categorized Primary Forest Top Mountains.

Group II consists of R. hoffmani, species are also found throughout the habitat types, plantations, degraded forest, pine forest, secondary forest and primary forest (1300-2200 m asl). The number of individuals who were observed at the next plantation habitats found in degraded forests habitats and primary forests. The least amount was found in pine forests.

Group III consists of R. dommermani, this species is found throughout almost the type of habitat that is plantation (1300 $\mathrm{m}$ asl), degraded forests (1500 m asl) secondary forest (1900 $\mathrm{m}$ asl) and Primary Forest (2200 $\mathrm{m}$ asl). The number of individuals who were observed at the next plantation habitats found in degraded forests and primary forests. While the least amount was found in secondary forest, this species is not at all found in pine forests.

\section{Group IV consists of two sub-groups:}

Sub IVa group comprised of the species B. chrysocomus, $B$. andrewsi, and B. Heinrici, three species have almost filled the entire habitat although the amount is not equal Rattus group. B. chrysocomus species found only in four types of habitat are degraded forest, pine forest, secondary forest and primary forest (1500 - $2200 \mathrm{~m}$ asl). The highest number of this species found in primary forest habitat while the least amount contained in the degraded forest, B. andrewsi also found in four habitat types. They are plantations, degraded forest, secondary forest and primary forest. The number of these species most commonly found in degraded forest habitats, while the least amount was found in habitat plantation. This type did not find in the pine forest.

As for the species, B. Heinrici is very different from Bunomys another group. This species is only found in three types of habitat, and the species of the least discovered that habitat of degraded forest, secondary forest and primary forest. The most commonly found in forest habitats are degraded, whereas in secondary forest habitat and primary forests have the same amount which is the lowest number.

$\mathrm{IVb}$ subgroup consists of two genera, that is Taeromys and Paruromys genus is endemic Sulawesi, Taeromys genus consists of two species namely $T$. celebensis, where the species is only found in two types of forest habitat is degraded primary forests. The number of the most widely found in degraded forest habitats. As for T. hamatus found only in forest habitats are degraded by the number of individuals that is 2 individuals. Furthermore, Genus Paruromys which are the most rarely found in the lowest height, P. dominator only found at an altitude of $2200 \mathrm{~m}$ above sea level, which is of primary forests, the amount found was very little that is just one individual. Paruromys sp, species has not been classified clearly. It was found in primary habitats with some individuals at least that one individual, to subgroups IVb very limited due to environmental factors. It can only be found in moist areas and low temperatures, as well as adaptation to the genus the very different from the genus Rattus and Bunomys.

The genus of Rattus is usually present in a variety of habitat types, including disturbed land or agriculture. In the Philippines, the genus is found in all kinds of altitude in the area of agriculture, tropical and subtropical forests, pine forests, as well as on human settlements [9]. Genus Bunomys commonly found in primary forests although they can also be 
found in the little-disturbed woods, the genus is most commonly found on the banks of the river, they eat small frogs and lizards, as well as earthworms [3]. Musser suggests that the species of rat forest widespread and common in Sulawesi is Rattus hoffmani [8], the species is also distributed in all types of habitat in Bawakaraeng Mount and abundant in the mountains above the altitude of 1900-2200 m above sea level. Lore Lindu National Park, Bunomys penitus, Paruromys dominator, Margaretamys elegans, Maxomys wattsi and Melasmothrix naso choose forest at an altitude of 600-1800 m above sea level [8].

\section{CONCLUSION}

A total of 227 rats captured in the area of Bawakaraeng Mount, South Sulawesi using dead traps and live traps at five different altitude levels. Grouping by Euclidian index rats divided into four groups categorized relate to the location of the arrest. The results of the dendrogram analysis of rats habitat type and altitude levels indicate that the habitat preferences at the site of primary forest $(2200 \mathrm{~m}$ asl $)$ and forest degradation $(1500 \mathrm{~m}$ asl) is more dominant than the other habitats. Species found in closely related types of habitat and food resources micro-climate factors such as temperature and humidity.

\section{REFERENCE}

[1] A. Suyanto, M. Yoneda, I. Maryanto, H. S. Maharadatunkamsi, and J. Sugardjito, "Checklist of the mammals of Indonesia," LIPI-JICA Jt. Proj. Biodivers. Conserv. Indones., 1998.

[2] K. P. Aplin, P. R. Brown, J. Jacob, C. J. Krebs, and G. R. Singleton, "Field methods for rodent studies in Asia and the Indo-Pacific," 2003.

[3] G. G. Musser and Y. M. D. CARLETON, "Superfamily Muroidea. Pp. 894-1531in Mammal species of the World, a taxonomic and geographic reference (Wilson, DE, y DM Reeder, eds.)." The John Hopkins University Press. Baltinore, EE. UU, 2005.

[4] M. D. Johnson and C. M. Horn, "Effects of rotational grazing on rodents and raptors in a coastal grassland," West. North Am. Nat., vol. 68, no. 4, pp. 444-452, 2008.

[5] L. R. Heaney, J. S. Walsh, and A. Townsend Peterson, "The roles of geological history and colonization abilities in genetic differentiation between mammalian populations in the Philippine archipelago," $J$. Biogeogr., vol. 32, no. 2, pp. 229-247, 2005.

[6] I. Maryanto and S. Higashi, "Comparison of Zoogeography among rats, fruit bats and insectivorous bats on Indonesian Islands," TREUBIA, vol. 38, pp. 33-52, 2011.

[7] N. Myers, R. A. Mittermeier, C. G. Mittermeier, G. A. B. Da Fonseca, and J. Kent, "Biodiversity hotspots for conservation priorities," Nature, vol. 403, no. 6772, pp. 853-858, 2000.

[8] G. G. Musser, Sulawesi rodents: descriptions of new species of Bunomys and Maxomys (Muridae, Murinae). American Museum of Natural History, 1991.

[9] K. R. Barbehenn, J. P. Sumangil, and J. L. Libay, "Rodents of the Philippine croplands.," Philipp. Agric., vol. 61, no. 7-8, pp. 217-242, 1972. 